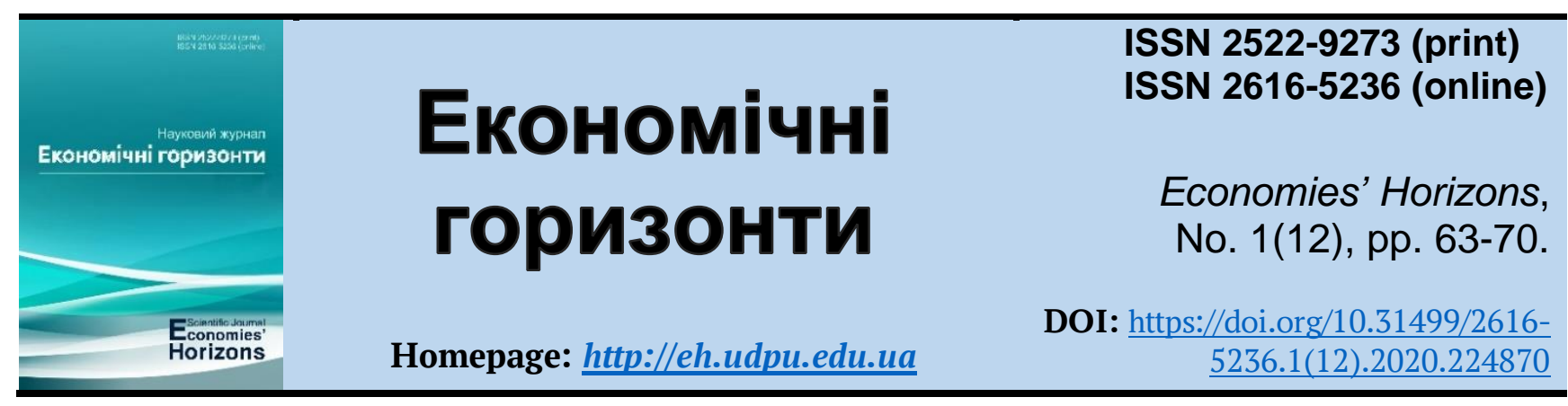

UDC 33.025.12:614

\title{
Analysis of the current state of health care state regulation
}

\author{
Dmytro M. Riabets ${ }^{1}$
}

Received: 14 February 2020

Ryabets, D. M. (2020), "Analysis of the current state of health care state regulation", Accepted: 16 March 2020

\begin{abstract}
Economies' Horizons, no. 1(12), pp.63-70, doi: https://doi.org/10.31499/26165236.1(12).2020.224870
\end{abstract}

\begin{abstract}
The purpose of the article is to analyse the current state of regional media platforms, identify development problems and justify solutions. Methodology. General scientific methods are used in the research, in particular: theoretical generalization - to determine the main provisions of health care; statistical analysis - to study the dynamics of medical care funding of state structures employees; methods of positive and normative analysis - to develop recommendations for improving the provision of medical services and the state of health care. Results. It was studied that in 2019, among 14,934.9 households, only 8.7\% considered their income level sufficient. And $40.2 \%$ of households could not afford basic necessities other than food. More than $50 \%$ of households said that if incomes increased, they would spend more on treatment. The largest share of households that noted the need for additional treatment costs has an average per capita equivalent cash income per month at the level of 1,920.1-2,640.0 UAH. At the same time, out of the total number of 14,644.5 thousand households, 98.4\% noted the need for health services during the year. Statistics show that in 2019, compared to 2018, the number of households that were unable to receive medical care, medicines and medical supplies for family members during the year increased. This trend is observed for both urban and rural residents. As a result, the ecological situation and the human living environment are deteriorating. Threats are created not only for the current population, but also for the lives of future generations. And according to the self-assessment of the health status of the Ukrainian population in 2019, only half of the population (50.4\%) marked their condition as good, the rest reported satisfactory $(39.5 \%)$ and poor (10.1\%). Practical meaning. It is revealed that the state of the environment is under threat due to certain prohibitions and restrictions on the control of economic activity in order to ensure favourable conditions for business development which creates an uncontrolled situation of use of natural resources (water, air, land) included in domestic turnover. Prospects for further research. According to the Law of Ukraine "On Basic Principles of State Supervision (Control) in the Field of Economic Activity" it is necessary to warn in advance and clearly define the list of issues and indicators of the economic activity inspection. This distorts the real picture of possible damage to the environment from improper economic activities and unbalanced use of natural resources.
\end{abstract}

Keywords: state regulation, health care, principles, funding, reimbursement.

JEL Classification: I10, I11, I18.

Number of references: 16; number of tables: 2; number of figures: $\mathbf{0}$; number of formulas: $\mathbf{0 .}$

\footnotetext{
${ }^{1}$ Black Sea Research Institute of Economics and Innovation; Applicant; ORCID ID: https://orcid.org/0000-00018540-1409; e-mail: management@nuos.edu.ua; Scientific Adviser - I. O. Irtyshcheva, Doct. Ec. Sc., Professor.
} 


\title{
Аналіз сучасного стану державного регулювання сфери охорони здоров'я
}

\author{
Дмитро Миколайович Рябець ${ }^{1}$
}

Стаття надійшла: 14.02 .2020 Стаття прийнята: 16.03.2020
Ryabets D. M. Analysis of the current state of health care state regulation. Економічні горизонти. 2020. № 1(12). C. 63-70. DOI: 10.31499/26165236.1(12).2020.224870

Анотація. Метою статті є аналіз сучасного стану забезпечення регіональними медіа платформи, виявлення проблем розвитку та обгрунтування шляхів вирішення. Методологія. У досліджені застосовані загальнонаукові методи, зокрема: теоретичного узагальнення - для визначення основних положень сфери охорони здоров’я; статистичного аналізу - для дослідження динаміки фінансування медичного обслуговування співробітників державних структур; методи позитивного і нормативного аналізу - для вироблення рекомендацій з удосконалення надання медичних послуг та стану сфери. Результати. Досліджено, що за 2019 рік, серед 14934,9 домогосподарств тільки 8,7\% вважали свій рівень доходів достатнім, а 40,2\% домогосподарств були вимушені постійно відмовляти собі у найнеобхіднішому, крім харчування. Понад 50\% домогосподарств зазначили, що при збільшенні доходів, вони б спрямували додаткові кошти в першу чергу на лікування. Найбільша частка домогосподарств, що відмітили необхідність додаткових витрат на лікування, із середньодушовими еквівалентними грошовими доходами у місяць на рівні 1920,1-2640,0 грн. У 2019 році із 14644,5 тисяч домогосподарств, у яких протягом року члени сім'ї потребували послуг сфери охорони здоров'я, аж 3574,4 тисяч домогосподарств не змогли їх отримати, що становить 24\%. При цьому із загальної кількості 14644,5 тисяч домогосподарств, визнали наявність протягом року потреби у послугах сфери охорони здоров'я аж 98,4\%. Статистичні дані свідчать, що у 2019 році порівняно із 2018 роком зросла кількість домогосподарств, у яких не змогли протягом року отримати медичну допомогу, придбати ліки та медичне приладдя для членів сім'ї. Така тенденція спостерігається і для мешканців міст і для сільського населення. В результаті погіршується екологічна ситуація та середовище життєдіяльності людини. Створюються загрози не тільки для теперішнього населення, а і для життєдіяльності майбутніх поколінь. А згідно самооцінки стану здоров'я населення України за 2019 рік тільки половина населення $(50,4 \%)$ відмітили свій стан як добрий, решта зазначили про задовільний $(39,5 \%)$ та поганий стан $(10,1 \%)$. Практичне значення. Виявлено, що загрозливою є ситуація із станом довкілля через накладення певної заборони та обмежень контролю господарської діяльності задля забезпечення сприятливих умов розвитку бізнесу, що створює безконтрольну ситуацію використання природних ресурсів (вода, повітря, земля) включених у внутрішньогосподарський оборот. Перспективи подальших досліджень. Згідно Закону України «Про основні засади державного нагляду (контролю) у сфері господарської діяльності» необхідно завчасно попередити та чітко визначити перелік питань і показників перевірки господарської діяльності, що спотворю реальну картину можливого нанесення шкоди навколишньому середовищу від некоректного ведення господарської діяльності та незбалансованого використання природних ресурсів.

Ключові слова: державне регулювання, сфера охорони здоров'я, принципи, фінансування, реімбурсація.

Кількість джерел: 14; кількість таблиць: 2 кількість рисунків: 0; кількість формул: 0.

\footnotetext{
${ }^{1}$ Причорноморський науково-дослідний інститут економіки та інновацій; здобувач; ідентифікатор ORCID: https://orcid.org/0000-0001-8540-1409; e-mail: management@nuos.edu.иа; науковий керівник I. О. Іртищева, д. е. н., професор.
} 


\section{Introduction.}

In civilized countries, health care is a priority of public policy. The state is responsible for the health of present and future generations, the preservation of the gene pool, which necessitates the recognition of the health care priority. At the national level, the basic principles of health care are being formed through the use of the regulatory and legal support and modern funding and management mechanisms in order to provide citizens with qualified medical care and conditions for a healthy lifestyle.

\section{Literature review.}

Peculiarities of the analysis of the current state of health care regulation have been studied by Ukrainian and foreign scientists, in particular: M. Tretyakov and I. Lapichak (2004), I. Irtyshcheva and I. Kramarenko (2014), K. Horbunova (2017), K. Dmytryk (2018), O. Pyshchulina, T. Yurochko, M. Mishchenko and Ya. Zhalilo (2018) and others. However, the constant reform processes and changes in the legal framework, the development of strategically important documents for the state require additional research in this area.

\section{Methodology.}

The theoretical and methodological basis of the study is the scientific works of scientists in the field of state regulation of health care. The following research methods were used to achieve the goals of the Paper: theoretical generalization - to determine the main provisions of health care; statistical analysis to study the dynamics of medical care funding of state structures employees; methods of positive and normative analysis - to develop recommendations for improving the provision of medical services and the state of health care.

\section{Research objectives.}

The purpose of the article is to analyze the current state of health care state regulation.

\section{Results and discussions.}

Among the main acts of regulatory and legal support in the field of health care is the Constitution of Ukraine (The Verkhovna Rada of Ukraine, 1996), the Law of Ukraine "Fun- damentals of the legislation of Ukraine on health care" (The Verkhovna Rada of Ukraine, 1993) and The Civil Code of Ukraine (The Verkhovna Rada of Ukraine, 2003).

State health policy is based on the principles of priority, guarantee, humanistic and social orientation, equality, science and innovation, financial security, prevention, sustainability, entrepreneurship and competition promotion, and subsidiarity. The Law of Ukraine "Fundamentals of the legislation of Ukraine on health care" (The Verkhovna Rada of Ukraine, 1993) contains a detailed justification of the basic principles of health care (Table 1). There is a network of medical institutions that provide health care services to ensure the realization of citizens' rights to health care in Ukraine. For the same purpose, the guaranteed volume of medical services for citizens is financed. Also the state control over the quality of health care services is provided using statistical information compiled at the state and regional levels. The Civil Code of Ukraine (The Verkhovna Rada of Ukraine, 2003) establishes liability for violations of citizens' rights in the field of health care.

There are five types of medical care guaranteed by the state on the basis of free medical services: emergency, primary, secondary, tertiary, palliative.

Despite the rights of citizens in the field of health care, it is mandatory for every citizen to take care of their own health and not to harm the health of others. It is important to prevent the disease through preventive examinations and timely vaccinations.

There are different types of health care system that correspond to different conceptual principles of health care system organization Typological features of the health system of Ukraine "are based on the principles of the English model, which is gradually being implemented in both legislative and medical practice. They are manifested in the forms of family and private medicine, insurance, multisource funding, high social standards" (Byrne, Ezer, Cohen, Overall and Senyuta, 2012). 


\section{Table 1. The main provisions of health care}

\begin{tabular}{|c|c|}
\hline The title of the normative act & Provisions, categories \\
\hline The Constitution of Ukraine & $\begin{array}{l}\text { The duty of the state is to protect human life. Everyone has the right to } \\
\text { protect his life and health, the lives and health of others against unlawful } \\
\text { encroachments (The Verkhovna Rada of Ukraine, 1996). }\end{array}$ \\
\hline $\begin{array}{l}\text { Law of Ukraine "Fundamentals of } \\
\text { the legislation of Ukraine on } \\
\text { health care" }\end{array}$ & $\begin{array}{l}\text { Health is a state of complete physical, mental and social well-being, but } \\
\text { not merely the absence of disease or infirmity (The Verkhovna Rada of } \\
\text { Ukraine, 1993). }\end{array}$ \\
\hline $\begin{array}{l}\text { Law of Ukraine "Fundamentals of } \\
\text { the legislation of Ukraine on } \\
\text { health care" }\end{array}$ & $\begin{array}{l}\text { Health care is "a system of measures carried out by public authorities } \\
\text { and local governments, their officials, health care institutions, individual } \\
\text { entrepreneurs who are registered in the manner prescribed by law and } \\
\text { have a license for medical practice, medical and pharmaceutical work- } \\
\text { ers, public associations and citizens in order to preserve and restore } \\
\text { physiological and psychological functions, optimal human performance } \\
\text { and social activity at the maximum biologically possible individual life } \\
\text { expectancy" (The Verkhovna Rada of Ukraine, 1993). }\end{array}$ \\
\hline $\begin{array}{l}\text { Law of Ukraine "Fundamentals of } \\
\text { the legislation of Ukraine on } \\
\text { health care" }\end{array}$ & $\begin{array}{l}\text { Medical care is "the activity of professionally trained medical workers } \\
\text { aimed at prevention, diagnosis, treatment and rehabilitation due to dis- } \\
\text { eases, injuries, poisonings and pathological conditions, as well as due to } \\
\text { pregnancy and childbirth" (The Verkhovna Rada of Ukraine, 1993). }\end{array}$ \\
\hline $\begin{array}{l}\text { Law of Ukraine "Fundamentals of } \\
\text { the legislation of Ukraine on } \\
\text { health care" }\end{array}$ & $\begin{array}{l}\text { Medical subsidy is "a non-cash benefit provided at the expense of state } \\
\text { or local budgets to pay for the patient's medical services and medicines" } \\
\text { (The Verkhovna Rada of Ukraine, 1993). }\end{array}$ \\
\hline $\begin{array}{l}\text { Law of Ukraine "Fundamentals of } \\
\text { the legislation of Ukraine on } \\
\text { health care" }\end{array}$ & $\begin{array}{l}\text { Medical service "the activity of health care institutions and individual } \\
\text { entrepreneurs who are registered and licensed in the manner prescribed } \\
\text { by law, in the field of health care, which is not necessarily limited to } \\
\text { medical care, but is directly related to its provision" (The Verkhovna } \\
\text { Rada of Ukraine, 1993). }\end{array}$ \\
\hline
\end{tabular}

The highest body of the Ukrainian health system is the Ministry of Health of Ukraine $(\mathrm{MOH})$, which works closely with other central executive bodies. The Ministry of Health subordinates and coordinates the work of all health care facilities.

"Health care is financed from the State Budget of Ukraine and local budgets, health insurance funds, charitable foundations and any other sources that are not prohibited by law". Unfortunately, this norm of the law is not fully complied with in Ukraine. After all, the growth rate of state budget expenditures on health care does not correspond to the accelerated growth rate of prices for medicines and medical equipment, which makes it impossible for the health care system to function properly (Dmytryk, 2018).

According to the WHO, a level of GDP funding of 6 to $8 \%$ of is needed to ensure the effective functioning of the health care system. And in the state budget of Ukraine this indicator does not exceed $3 \%$ in recent years (Horbunova, 2017).

According to the Law of Ukraine "On state financial guarantees of medical care", the lower limit of state budget expenditures for the implementation of medical guarantees was set at 5\% of Ukraine's GDP, but, unfortunately, this provision was suspended (The Verkhovna Rada of Ukraine, 2018).

In 2020, state budget expenditures for the Ministry of Health were almost doubled compared to 2019 and set at UAH 98.2 billion (Table 2). Nevertheless, funds were redistributed between the Ministry of Health, the State Service of Ukraine on Medicines and Drugs Control, and the National Health Service of Ukraine (NHSU). So that is unclear how it will affect the health of citizens (Horbunova, 2017). After all, despite the reform of health care funding and the introduction of the principle of "money follows the patient", the effectiveness of change has not yet been felt by 
ordinary citizens, it can only be expected in a few years. The increase in expenditures on national institutions and activities in the field of medical education is considered positive. In 2019, UAH 2.5 million was allocated for this program, and UAH 364.5 million was provided for 2020. However, there was a decrease in funding for medical care for certain categories of the population, including government employees.

\section{Table 2. Dynamics of medical care funding for government employees}

\begin{tabular}{|c|c|c|c|}
\hline $\begin{array}{l}\text { Name according to the departmental and program classifications of } \\
\text { expenses and lending to the state budget }\end{array}$ & $\begin{array}{c}2019 \\
\text { UAH } \\
\text { million } \\
\end{array}$ & $\begin{array}{c}2020 \\
\text { UAH } \\
\text { million }\end{array}$ & $\begin{array}{l}\text { Growth/ } \\
\text { decrease } \\
\text { rates, \% }\end{array}$ \\
\hline Provision of medical services by medical institutions & 833.1 & 793.2 & -4.8 \\
\hline $\begin{array}{l}\text { Specialized prosthetic and orthopedic care and medical rehabilitation assis- } \\
\text { tance for people with disabilities in the Research State Institute for Prosthesis } \\
\text { Design, Prosthetic Building and Work Ability Rehabilitation }\end{array}$ & 27.0 & 29.1 & +7.8 \\
\hline $\begin{array}{l}\text { Sanatorium treatment of war veterans, people covered by the Laws of Ukraine } \\
\text { "On the status of war veterans, guarantees of their social protection", "On } \\
\text { victims of NAZI persecution" and people with disabilities }\end{array}$ & 198.3 & 212.9 & +7.3 \\
\hline $\begin{array}{l}\text { Medical care and rehabilitation of personnel and maintenance of preschool } \\
\text { educational institutions of the Security Service of Ukraine }\end{array}$ & 231.4 & 241.0 & +4.1 \\
\hline Medical care for employees of the National Academy of Sciences of Ukraine & 367.5 & 93.1 & -74.7 \\
\hline $\begin{array}{l}\text { Measures for psychological rehabilitation, social and professional adaptation, } \\
\text { provision of sanatorium treatment for victims of the } 2014 \text { Ukrainian Revolu- } \\
\text { tion, participants in the War in Donbass and persons who took measures to } \\
\text { ensure national security and defense, repel and deter armed aggression in the } \\
\text { Donetsk and Luhansk regions }\end{array}$ & 112.7 & 246.4 & +118.7 \\
\hline Total & $1,770.0$ & $1,615.8$ & -8.7 \\
\hline
\end{tabular}

Source: (Dmytryk, 2018; 2019)

Since 2020, Ukraine has introduced reimbursement of the medicine cost (ensuring availability), provided by the medical guarantee program. The implementation of this program is assigned to the National Health Service of Ukraine. And from the state budget on it is executed. And for its implementation it is planned to allocate UAH 72 billion from the state budget. Areas of funding for this program are described in the figure.

Unfortunately, the declared rights and guarantees in the field of health care are not fully implemented in Ukraine. Ukraine does not have a comprehensive strategic normative document on ensuring the health of citizens. Thus, in 2011, attempts were made to adopt the Health 2020: Ukrainian Dimension program (Cabinet of Ministers of Ukraine, 2011). It all ended only with the approval of the Concept of this program by the Cabinet of Ministers, but the program was never adopted. There are problems in the field of healthy lifestyle policy, because in Ukraine advertising of medicines is not prohibited and the pe- culiarities of selling alcoholic beverages are not regulated.

There are also problems with the access of the population to health services, which are most often related to the inability to pay for them. According to State Statistics Service, about $30 \%$ of the population is unable to receive medical services due to lack of adequate income.

According to 2019 statistics, among 14,934.9 households, only $8.7 \%$ considered their income level sufficient. And $40.2 \%$ of households could not afford basic necessities other than food. More than $50 \%$ of households said that if incomes increased, they would spend more on treatment. The largest share of households that noted the need for additional treatment costs has an average per capita equivalent cash income per month at the level of 1,920.1 - 2,640.0 UAH.

The environment is under threat due to certain prohibitions and restrictions on the control of economic activity in order to ensure favorable conditions for business devel- 
opment which creates an uncontrolled situation of use of natural resources (water, air, and land) included in domestic turnover. Thus, according to the Law of Ukraine "On Basic Principles of State Supervision (Control) in the Field of Economic Activity" it is necessary to warn in advance and clearly define the list of issues and indicators of the economic activity inspection (The Verkhovna Rada of Ukraine, 2019). This distorts the real picture of possible damage to the environment from improper economic activities and unbalanced use of natural resources. As a result, the ecological situation and the human living environment are deteriorating. Threats are created not only for the current population, but also for the lives of future generations. And according to the self-assessment of the health status of the Ukrainian population in 2019 , only half of the population (50.4\%) marked their condition as good, the rest reported satisfactory (39.5\%) and poor (10.1\%).

According to the Law of Ukraine "On Amendments to the Fundamentals of Health Legislation of Ukraine regarding Improvement of Medical Assistance", the network of state and municipal health care institutions cannot be reduced in order to ensure an adequate level of medical care for citizens (The Verkhovna Rada of Ukraine, 2012). However, the closure of hospitals and other medical institutions for various reasons is known. And the existing network of state and municipal institutions cannot cope with the existing needs of citizens in providing medical services. Therefore, it makes it necessary for citizens to seek medical care on a paid basis in commercial institutions. Studies of informal payments in the field of health care showed that their share reaches $40 \%$. Ukraine leads among other post-Soviet states in terms of informal payments in the field of medicine. This is also complicated by the fact that Ukrainians already receive insufficient health care services.

According to the State Statistics Service of Ukraine, in 2019, out of $14,644.5$ thousand households in which family members needed health care services during the year, 3,574.4 thousand households could not receive them, which is $24 \%$. At the same time, out of the total number of $14,644.5$ thousand households, $98.4 \%$ noted the need for health services during the year.

Among the types of health services required, statistics keep records of households for the inability to purchase medicines and medical supplies, visit a doctor or dentist, conduct a medical examination, and receive the necessary treatment and medical procedures. Excessive costs are often cited as the reasons for not being able to receive health care services. But in many cases the reason is the lack of a medical specialist and even the lack of vacancies or the lack of a certain department.

Statistics show that in 2019, compared to 2018, the number of households that were unable to receive medical care, medicines and medical supplies for family members during the year increased. This trend is observed for both urban and rural residents.

Thus, it cannot be argued that there is a general availability of medical services, as a quarter of the population of Ukraine could not get them for various reasons.

It should be noted that the inability of the population to pay for the necessary health care services and the lack of state funding for these services is explained by the fact that there are restrictions on the state budget size, which are declared in the Constitution of Ukraine (The Verkhovna Rada of Ukraine, 1996).

Special attention needs to be paid to the provision of medical services and the state of health care in rural areas. After all, the most common reason for not receiving medical services in rural areas is the lack of departments and medical specialists. "The understaffing of ambulant clinics in rural areas averages $70 \%$. Often, even nurses do not work every day, and there is no Internet at all".

In Ukraine, the situation with the health 
care infrastructure in terms of the development of physical education of the population is difficult. We agree with the opinion that "The complexity and ambiguity of the recent problems in the field of physical education and sports require the development of new conceptual approaches to the formation of the staffing system of the industry. The approaches should make it possible to comprehensively identify new trends, ensure the compliance of personnel policy with the state interests and the needs of the labor market. This approach is based on the development of physical education standards, which set requirements for the content, scope and level of staff training" (Tretyakov and Lapichak, 2004).

The issue of doubtful changes in the health care infrastructure of Ukraine also concerns the liquidation of the State Sanitary and Epidemiological Service (Cabinet of Ministers of Ukraine, 2017). Despite the transfer of some powers to the State Service of Ukraine on Food Safety and Consumer Protection, the inconsistency of the relevant regulatory provision and the loss of the part of the control functions on food safety and prevention of harm to public health are monitored.

So, guaranteed and legally enshrined rights of Ukrainian citizens to health care are mostly declarative. The declarative nature of health guarantees is often due to a lack of funding. Moreover, this applies to the level of the state and the inability of individual citizens to pay for the necessary medical services. All this contradicts European living standards and the Sustainable Development Goals. These arguments call for the need to improve the organizational and managerial framework for the regulation of health care in Ukraine in the direction of providing the population with quality medical services and improving the health of the nation (The Community Research and Development Information Service, 2013). It is necessary to change the conscious view of the Ukrainian health care system in the context of improving the living standards of the population, improving human development and meeting the Sustainable Development Goals, in particular by strengthening self-responsibility for health and strengthening the patient-centered health care system.

\section{Conclusions.}

It was studied that in 2019, among 14,934.9 households, only $8.7 \%$ considered their income level sufficient. And $40.2 \%$ of households could not afford basic necessities other than food. More than 50\% of households said that if incomes increased, they would spend more on treatment. The largest share of households that noted the need for additional treatment costs has an average per capita equivalent cash income per month at the level of 1920.1 - 2640.0 UAH. At the same time, out of the total number of 14,644.5 thousand households, 98.4\% noted the need for health services during the year. Statistics show that in 2019, compared to 2018, the number of households that were unable to receive medical care, medicines and medical supplies for family members during the year increased. This trend is observed for both urban and rural residents.

It is revealed that the state of the environment is under threat due to certain prohibitions and restrictions on the control of economic activity in order to ensure favorable conditions for business development which creates an uncontrolled situation of use of natural resources (water, air, land) included in domestic turnover. Thus, according to the Law of Ukraine "On Basic Principles of State Supervision (Control) in the Field of Economic Activity" it is necessary to warn in advance and clearly define the list of issues and indicators of the economic activity inspection. This distorts the real picture of possible damage to the environment from improper economic activities and unbalanced use of natural resources. As a result, the ecological situation and the human living environment are deteriorating. Threats are created not only for the current population, but also for the lives of future generations. And according to the self-assessment of the health status of the 
Ukrainian population in 2019 , only half of the good, the rest reported satisfactory (39.5\%) population (50.4\%) marked their condition as and poor $(10.1 \%)$.

\section{References}

Byrne, I., Ezer, T., Cohen, J., Overall, J. and Senyuta, I. (ed.) (2012), Human Rights in Patient Care: A Practitioner Guide, LOBF Publishing House "Medicine and Law", Lviv, Ukraine, 497 p., available at: https://www.irf.ua/files/ukr/programs/health/human_rights_in patient_care.pdf (Accessed 3 February 2020)

Cabinet of Ministers of Ukraine (2011), Order "On approval of the concept of the national program "Health 2020: Ukrainian dimension", available at: https://www.kmu.gov.ua/npas/244717787 (Accessed 3 February 2020)

Cabinet of Ministers of Ukraine (2017), Resolution "Some issues of the state sanitary and epidemiological service", available at: https://www.kmu.gov.ua/npas/250003281 (Accessed 3 February 2020)

Dmytryk, K. (2018), "What is next year preparing for us? General indicators and expenditures on health care of the State Budget 2018”, available at: https://www.apteka.ua/article/440833 (Accessed 3 February 2020)

Dmytryk, K. (2019), "State Budget 2020: general indicators and expenditures on health care", available at: https://www.apteka.ua/article/525932 (Accessed February 2020)

Horbunova, K. (2017), “State Budget-2017: The health care system in numbers", available at: https://www.apteka.ua/article/397685 (Accessed 3 February 2020)

Irtyshcheva, I. O. and Kramarenko, I. S. (2014), "Investment attractiveness of the economy: inter-regional asymmetries”, Regional economy, no. 2 (72), pp. 84-95

Pyshchulina, O., Yurochko, T., Mishchenko, M. and Zhalilo, Ya. (2018), Rozvytok liudskoho kapitalu: na shliakhu do yakisnykh reform [Human capital development: on the way to quality reforms], Razumkov Centre, Kyiv, Ukraine, 367 p., available at: http://razumkov.org.ua/uploads/article/2018 LUD KAPITAL.pdf (Accessed 3 February 2020)

The Community Research and Development Information Service (2013), "Assessment of patient payment policies and projection of their efficiency, equity and quality effects. The case of Central and Eastern Europe”, ASSPRO CEE 2007 - Project No. 217431, available at: http://www.assprocee2007.com (Accessed 3 February 2020)

The Verkhovna Rada of Ukraine (1993), Law of Ukraine "Fundamentals of the legislation of Ukraine on health care", available at: https://zakon.rada.gov.ua/laws/show/2801-12\#Text (Accessed 3 February 2020)

The Verkhovna Rada of Ukraine (1996), "Constitution of Ukraine", available at: https://zakon.rada.gov.ua/laws/show/254\%D0\%BA/96-\%D0\%B2\%D1\%80\#Text (Accessed 3 February 2020)

The Verkhovna Rada of Ukraine (2003), "The Civil Code of Ukraine", available at: https://zakon.rada.gov.ua/laws/show/435-15\#Text (Accessed 3 February 2020)

The Verkhovna Rada of Ukraine (2012), Law of Ukraine "On amendments to the fundamentals of legislation on health care to improve the provision of medical care", available at: https://zakon.rada.gov.ua/laws/show/3611-17\#Text (Accessed 3 February 2020)

The Verkhovna Rada of Ukraine (2018), Law of Ukraine "On state financial guarantees of medical care", available at: https://zakon.rada.gov.ua/laws/show/2168-19\#Text (Accessed 3 February 2020)

The Verkhovna Rada of Ukraine (2019), Law of Ukraine "On basic principles of state supervision (control) in the sphere of economic activity", available at: https://zakon.rada.gov.ua/laws/show/877-16\#Text (Accessed 3 February 2020)

Tretyakov, M. O. and Lapichak, I. E. (2004), "The state of professional knowledge and skills of students of higher educational institutions of physical culture", Theory and practice of physical education, no. 2, pp. 42-49.

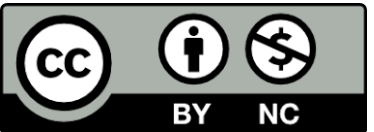

Цей твір ліцензовано на умовах Ліцензії Creative Commons «/з Зазначенням Авторства - Некомериійна 4.0 Міжнародна» (CC BY-NC 4.0). This is an open access journal and all published articles are licensed under a Creative Commons "Attribution-NonCommercial 4.0 International" (CC BY-NC 4.0). 